\title{
Pengaruh Kompetensi Diri Terhadap Kinerja Pekerja GKII Daerah Kota Samarinda
}

\section{Effect of Self-Competence on Worker Performance GKII of Samarinda City Region}

\author{
Lenggan $)^{*}$ \\ 1) Sekolah Tinggi Teologi Tenggarong, Kalimantan Timur \\ ${ }^{*}$ Penulis korespondensi: lengganpait1977@gmail.com
}

Received: 24 April 2019/Revised: 11 May 2019/Accepted: 11 October 2019

\begin{abstract}
Abstrak
Dari hasil penelitian terdapat pengaruh yang positif dan sangat signifikan antara Kompetensi Diri dengan Kinerja Pekerja. Hal ini berarti semakin baik kompetensi diri para pekerja GKII Daerah Kota Samarinda maka semakin baik pula kinerjanya. Berdasarkan hasil analisis korelasi antara Dimensi Kompetensi Diri dengan kinerja dan analisis Classification and Regression Trees bahwa Dimensi Kompetensi kepribadian yang paling berpengaruh secara dominan terhadap peningkatan kinerja pekerja. Dengan meningkatkan kompetensi kepribadian menjadi lebih baik dan mampu memberikan keteladanan seperti Kristus dalam pelaksanaan tugas pelayanan maka kinerja pekerja akan semakin meningkat dan menjadi semakin baik.

Kata-kata Kunci: Kompetensi, Pelayanan, Organisasi, Kinerja, Gereja

From the results of the study, there is a positive and very significant effect between Self Competence and Worker Performance. It means that the better the competency of the GKII Regional Samarinda City employees, the better the performance. Based on the results of the correlation analysis between the Self Competency Dimensions with performance and Classification and Regression Trees analysis that the Personality Competency Dimensions are the most influential dominantly on increasing employee performance. By increasing personality competencies for the better and being able to exemplify as Christ in the implementation of service duties, the performance of workers will increasingly improve and become better.
\end{abstract}

Keywords: competence, service, organization, performance, church

\section{Pendahuluan}

Kompetensi diri perlu mendapatkan perhatian penuh dalam pengembangan pelayanan. Dari perbincangan penulis bersama beberapa 
pekerja dan anggota Badan Pengurus Daerah GKII Kota Samarinda, dijumpai bahwa: Pertama, secara formal dari 32 orang jumlah pekerja GKII Daerah Kota Samarinda, enam belas orang memiliki tingkat pendidikan strata dua, tiga orang strata tiga dan selebihnya strata satu. ${ }^{1}$ Ini berarti bahwa kompetensi akademis pekerja GKII Daerah Kota Samarinda cukup menjanjikan sebuah harapan besar bagi kemajuan pelayanan gereja secara umum. Namun jawaban kedua menjadi kurang relevan dengan jawaban pertama, bahwa kompetensi itu justru kurang terlihat dalam pelayanan, sekalipun tidak semua mengalami kemerosotan kualitas dan kuantitas, namun setidaknya apa yang terlihat dan tergambar dalam pengamatan beberapa anggota Badan Pengurus Daerah ini dapat memberikan indikasi bahwa ada sesuatu yang kurang tepat dijalankan oleh beberapa pekerja sehingga nilai kompetensi diri dan pelayanan menjadi kurang. Apakah mungkin pelayanan yang berjalan selama ini hanya merupakan tradisi dari periode ke periode sehingga nilai kompetensi menjadi kurang terlihat? Atau apakah nilai kompetensi sangat kurang dalam diri pekerja sehingga ada kecenderungan seperti ini, misalnya: cari aman saja, cukup saja yang ada, nikmati yang ada saja dan lain-lain.

Ada beberapa penelitian sebelumnya yang telah dilakukan sehubungan dengan penelitian kompetensi diri. Penelitian Parker \& Collins (2010) tentang persepsi kompetensi diri telah melaporkan hubungan positif dengan kinerja. Penelitian Dogan et al. (2013) hubungan positif kompetensi diri terhadap kesejahteraan psikologis. Penelitian Judge et al. (2007) tentang hubungan positif kompetensi diri dengan minat tugas dan penelitian Yakin \& Erdil (2012) tentang hubungan positif kompetensi diri dengan sikap terhadap organisasi. ${ }^{2}$ Kesimpulan penelitian William \& Lillibridge (1992) menunjukkan Kompetensi diri spesifik untuk situasi tertentu atau tugas tertentu, dan dapat dipengaruhi oleh efek bersama dari faktor situasional dan disposisi. ${ }^{3}$ Penelitian Battistelli et al. (2016) menunjukkan bahwa mendukung karyawan dengan memerhatikan kesejahteraan mereka serta mengembangkan bentuk positif dari komitmen organisasi menciptakan konteks yang sehat untuk pengembangan kompetensi diri. ${ }^{4}$

Bila dihubungan dengan maksud penulis untuk meneliti kompetensi diri terhadap kinerja pekerja maka hipotesis yang

${ }^{1}$ Data Statistik Gereja Kemah Injil Indonesia Daerah Kota Samarinda tahun 2016. Penelitian dilakukan dalam kurun waktu 2016-2017.

${ }^{2}$ Adalgisa Battistelli et al., "Perceived Organisational Support, Organisational Commitment and Self-Competence among Nurses: A Study in Two Italian Hospitals," Journal of Nursing Management 24, no. 1 (January 2016): 2, https://doi.org/10.1111/jonm.12287.

${ }^{3}$ Battistelli et al., 2.

${ }^{4}$ Battistelli et al., 9. 
diungkapkan oleh Berdicchia et al. (2016) dapat dijadikan sebagai asumsi awal. Ketika peningkatan pekerjaan meningkat, maka pekerja dengan tingkat kompetensi diri yang lebih tinggi akan lebih percaya diri tentang kemampuan mereka untuk mengatasi tantangan baru melalui perolehan sumber daya baru. Sebaliknya, pekerja dengan tingkat kompetensi diri yang lebih rendah menghadapi pekerjaan yang diperbesar akan kurang percaya diri tentang kemampuan mereka untuk memperoleh sumber daya yang diperlukan, sehingga mereka mungkin kurang cenderung mengambil inisiatif untuk meningkatkannya. ${ }^{5}$

Dengan demikian rumusan masalah dalam penelitian ini adalah apakah terdapat pengaruh kompetensi diri terhadap kinerja pelayanan pekerja Gereja Kemah Injil Indonesia Kota Samarinda?

\section{Kajian Teori}

Dalam bagian ini penulis memaparkan empat jenis kompetensi yang penulis anggap sangat penting bagi pengembangan diri dan pelayanan seorang pelayan Tuhan, yaitu: kompetensi spiritual, kompetensi profesional, kompetensi kepribadian dan kompetensi sosial.

\section{Kompetensi Spiritual}

Semua pemimpin besar telah memahami bahwa tanggung jawab nomor satu mereka adalah untuk disiplin dan pertumbuhan pribadi mereka sendiri. Kalau mereka tidak dapat memimpin diri mereka sediri, mereka tidak akan mungkin dapat memimpin orang lain. Inilah yang disebut oleh Maxwell "label harga kepemimpinan: Disiplin pribadi". 6 Beliau menegaskan lagi bahwa seorang besar akan memimpin sebuah organisasi besar, tetapi pertumbuhan hanya mungkin kalau pemimpin bersedia "membayar harga" untuk itu. Mencermati bagian ini, disiplin khususnya disiplin spiritual memainkan peranan penting dalam hidup pemimpin kristen. Sebab itu, otoritas sebuah pelayanan tidaklah ditentukan oleh kefasihan dan kepandaian seorang pelayan dalam mengomunikasikan injil kepada jemaatnya, walaupun hal tersebut memainkan peranan yang sangat penting dalam hidup seorang pemimpin. Namun dari banyak pengalaman tokoh-tokoh gereja bahkan tokoh-tokoh yang tercatat di dalam Alkitab, otoritas sebuah pelayanan

${ }^{5}$ Domenico Berdicchia, Francesco Nicolli, and Giovanni Masino, "Job Enlargement, Job Crafting and the Moderating Role of Self-Competence," Journal of Managerial Psychology 31, no. 2 (March 14, 2016), https://doi.org/10.1108/JMP-01-20140019.

${ }^{6}$ John C. Maxwell, Mengembangkan Kepemimpinan di dalam Diri Anda (Jakarta: Binarupa Aksara, 1995), 168. 
sangat bergantung pada sejauh mana seorang pemimpin bergaul akrab dengan Tuhan.

Disiplin rohani merupakan kegiatan yang sengaja dibuat oleh seorang pelayan Tuhan untuk membangun otot-otot rohaninya sehingga menjadi kekar dan kuat untuk menghadapi segala bentuk tantangan pelayanan karena itulah disiplin rohani tidak terjadi dengan sendirinya tetapi dijadwalkan atau disengajakan untuk dilatih, dibentuk sehingga menghasilkan ketaatan kepada kehendak Bapa. Disiplin rohani dimaksud adalah disiplin dalam doa dan disiplin dalam membaca Alkitab

\section{Kompetensi Profesional}

Kompetensi profesionalitas adalah kompetensi yang berhubungan dengan bidang kerja yang dijalankan oleh seorang pekerja dalam hubungannya dengan pelayanan dalam gereja. Tentu pekerjaanpekerjaan tersebut adalah tugas yang sudah lumrah dilakukan namun harus dilakukan secara profesional, seperti: Pertama, penginjil yang Memberitakan Injil. Bagian ini bermaksud untuk memberikan penegasan bahwa kompetensi evangelical adalah kemampuan untuk memberitakan injil kepada orang yang belum mengenal injil. "Kebutuhan utama manusia yang paling hakiki dan mendesak ialah penyelamatan rohnya, sebab manusia sudah mati karena pelanggaran-pelanggaran dan dosadosa,"7 demikian yang dikatakan oleh D. W. Ellis. Mencermati hal tersebut, maka seperti yang dikatakan dalam Kitab Efesus 2: 12 bahwa "manusia tanpa Kristus..., tanpa pengharapan dan tanpa Allah di dalam dunia." Demikian pula yang dikatakan dalam Yohanes 3: 16, 36 dan 2 Korintus 4: 3, bahwa "manusia menuju kepada kebinasaan di bawah murka Allah." Kenyataan ini memberikan arti tersendiri dalam hidup seorang hamba Tuhan, untuk itulah ia memasuki lingkaran pelayanan tersebut, yakni memberitakan kabar keselamatan kepada mereka yang tersesat dan belum mendengar kabar keselamatan di dalam Yesus. Ungkapan "celakalah aku jika aku tidak memberitakan injil, karena itu suatu keharusan bagiku" merupakan peringatan keras bagi gembala sidang tentang tugas dan tanggung-jawabnya dalam pemberitaan injil, ia harus pergi menjangkau mereka yang bukan umat Tuhan memasuki komunitas umat Tuhan. Kedua, gembala yang melayani dengan rendah hati yang tentu akan menjalankan tugasnya seperti: Pemberi makan umat, seorang konselor yang bertanggungjawab, seorang yang akan membawa kesembuhan bagi umat, menopang umat, membimbing umat, mendamaikan umat, memberdayakan umat dan mengutus umat. Ketiga,

${ }^{7}$ D. W. Ellis, Metode Penginjilan (Jakarta: Yayasan Komunikasi Bina Kasih/OMF, 1993), 13. 
sebagai seorang pendidik. Keempat, seorang pengkhotbah. Kelima, seorang Manajer yang mampu menata pelayanan. Keenam seorang pemimpin.

\section{Kompetensi Kepribadian}

"Kepribadian dalam bahas Inggris disebut personality. Kata personality ini sendiri, konon asalnya dari bahasa latin, persona, yang berarti topeng atau tutup muka ataupun masker." 8 Beberapa ahli memberikan pengertian yang berbeda dengan apa yang disampaikan di atas. Allport misalnya, beliau mendefinisikan kepribadian sebagai yang pendek dan yang panjang. Definisi yang pendek menurutnya: "Personality as what a man really is" sementara definisi panjangnya adalah "personality is the dynamic organization whithin the individual of those psichophysical system that

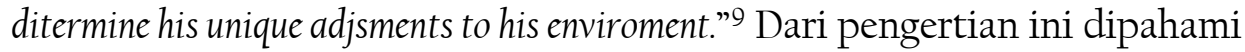
bahwa kepribadian adalah organisasi dinamis psikofisik dalam individu yang menentukan penyesuaiannya yang unik terhadap lingkungan sekitarnya.

Menurut Eysenck ada empat macam dimensi kepribadian, yaitu: Kecerdasan (intelegensi), karakter atau watak, afeksi (emosi dan tempramen) dan konstitusi tubuh atau jasmani. ${ }^{10}$ Pada akhirnya dari beberapa pengertian tersebut di atas jelaslah bahwa kepribadian merupakan kualitas total tingkah laku seseorang, yang ditunjukkan dalam kebiasaan cara berfikir dan ekspresinya, sikap dan interesnya cara berprilaku, dan filsafat hidupnya sendiri. Hal lain dikatakan oleh Ghazali tentang kepribadian adalah sebagai berikut:ll

1. Kepribadian adalah sekumpulan motivasi, kebutuhan dan pilihanpilihan seseorang yang berperan sebagai ekspresi spontan yang merupakan cetak biru kekuatan dan kelemahan seorang individu sebagai mana adanya.

2. Kepribadian adalah sejumlah sikap dan tingkah laku manusia yang merupakan keutuhan, serta sifat khas seseorang.

3. Kepribadian adalah kesatuan sistem jiwa dan raga dalam diri individu yang bersifat dinamis dan dapat menyesuaikan diri dengan lingkungan.

Dari uraian di atas tentu dapat dipahami bahwa kepribadian seorang pelayan akan menentukan kinerja pelayanan bahkan suksesi pelayanannya. Kepribadian yang baik pastilah menunjukkan kepribadian

${ }^{8}$ Ki Fudyartanta, Psikologi Kepribadian (Yogyakarta: Pustaka Pelajar, 2012), 28.

${ }^{9}$ Gordon W. Allport, dalam Ki Fudyartanta, Psikologi Kepribadian (Yogyakarta: Pustaka Pelajar, 2012), 29.

${ }^{10}$ Ki Fudyartanta, Psikologi Kepribadian (Yogyakarta: Pustaka Pelajar, 2012). Ki Fudyartanta mengutip pernyataan Eysenck.

${ }^{11}$ Muin Ghazali, Nurseha Ghazali, Deteksi Kepribadian (Jakarta: Bumi Aksara, 2016), 20. 
Kristus yang menjadi panutan dalam segala hal. Untuk itu indikatorindikator kepribadian yang baik sesuai dengan apa yang dikatakan Alkitab adalah seperti yang terdapat di dalam 1 Timotius 3:1-7, di sana jelas dikatakan: Seorang yang tidak bercacat, suami dari satu isteri, dapat menahan diri, bijaksana, sopan, suka memberi tumpangan, cakap mengajar orang, bukan peminum, bukan pemarah melainkan peramah, pendamai, bukan hamba uang, seorang kepala keluarga yang baik, disegani dan dihormati anak-anaknya, bukan seorang yang baru bertobat, punya nama baik di luar jemaat.

\section{Kompetensi Sosial}

Sanjaya menyatakan bahwa kompetensi sosial meliputi: pertama, kemampuan berinteraksi dan berkomunikasi dengan teman sejawat untuk meningkatkan kemampuan profesional. Kedua, kemampuan mengenal dan memahami fungsi-fungsi setiap lembaga kemasyarakatan, dan ketiga, kemampuan menjalin kerjasama, baik secara individual maupun secara kelompok.12 Dalam hubungannya dengan kompetensi sosial seorang pekerja atau pelayan tentu bagian ini memberikan penekanan kepada bagaimana seorang pelayan dapat bersosialisasi dengan semua lapisan dan golongan tanpa membuat skat atau pembatas yang dapat menghacurkan pelayanan secara keseluruhan. Karena itu keberhasilan pelayanannya sangat ditentukan dari kemampuannya dalam membangun hubungan dengan orang lain yang menjadi bagian dari kehidupan dan pelayanan yang dimandatkan kepadanya. Hubungan yang harmonis akan membuatnya mendapatkan dukungan untuk lebih mengembangkan semua gerakan pelayanan dengan leluasa, serta mampu mengatasi persoalan-persoalan yang terjadi di dalam pelayanannya. Keharmonisan hubungan dengan rekan kerja menjadikan seseorang dapat bersinergi, berdiskusi, dan mencari solusi bersama dalam memecahkan permasalahan pembelajaran. Hubungan harmonis dengan anggota jemaatnya juga menjadi kunci bagi seorang pelayan Tuhan dalam membina, membimbing dan menuntun orang lain sehingga dirinya mengalami keberhasilan dalam pelayanan.

\section{Kinerja Pekerja}

Sebagaimana yang telah dijelaskan di atas tentang kinerja, bahwa kinerja juga merupakan prestasi kerja, maka apa yang dikatakan oleh Simamora tentang prestasi kerja tersebut mempunyai indikatorindikator sebagai berikut: ${ }^{13}$

${ }^{12}$ Wina Sanjaya, Strategi Pembelajaran Berorientasi Standar Proses Pendidikan (Jakarta: Kencana Prenada Media Group, 2006), 18-19.

${ }^{13}$ Wibowo, Manajemen Kinerja (Jakarta: Kharisma Putra Utama Offset, 2016), 106. 
1. Keputusan terhadap segala aturan yang telah ditetapkan organisasi;

2. Dapat melaksanakan pekerjaan atau tugasnya tanpa kesalahan (atau dengan tingkat kesalahan yang paling rendah);

3. Ketepatan dalam menjalankan tugas. Ukuran prestasi kerja tersebut yang kemudian diterjemahkan ke dalam penilaian perilaku secara mendasar meliputi: 1) kualitas kerja; 2) kuantitas kerja; 3) pengetahuan tentang pekerjaan; 4) pendapat atau penyataan yang disampaikan; 5) keputusan yang diambil; 6) perencanaan kerja, dan 7) daerah organisasi kerja.

Tanpa dorongan motif untuk mencapai tujuan, kinerja tidak akan berjalan. Dengan demikian tujuan dan motif menjadi indikator utama kinerja."14

Dari beberapa uraian teori yang telah dipaparkan di atas, maka penulis dapat menyimpulkan beberapa poin penting terkait kinerja, bahwa kinerja pekerja dapat diukur dengan dimensi-dimensi sebagai berikut:

1. Kepatuhan terhadap aturan-aturan dan ketetapan organisasi, dengan indikator sebagai berikut:

a. Mampu menjalankan tugas dan tanggung jawabnya sesuai dengan fungsinya;

b. Bekerja hanya untuk kepentingang organisasi dan kemuliaan Tuhan;

c. Saling menghargai/respek.

2. Mampu menunjukkan prestasi kerja yang maksimal, dengan indikator sebagai berikut:

a. Melaksanakan tugas tanpa kesalahan atau tingkat kesalahan yang paling rendah (Kualitas);

b. Melaksanakan tugas tepat waktu (Kuantitas);

c. Tanggung jawab/Akuntabilitas.

3. Leadership and Management Effectiveness (Kepemimpinan dan Efektifitas manajemen). Artinya mampu menunjukkan kemampuan dalam memimpin dan menata pelayanan, dengan indikator sebagai berikut:

a. Kecerdasan;

b. Mampu bekerja sama dengan semua pihak;

c. Inovation and risk taking (Inovasi dan pengambilan risiko).

Penelitian yang Relevan: Kompetensi Diri terhadap Kinerja Pekerja adalah:

Beberapa penelitian yang relevan dengan topic penelitian ini

1. Kompetensi berpengaruh positif terhadap terhadap Kinerja Karyawan pada Rumah Sakit Ratumbuysang Manado. Kompetensi karyawan dapat menjalankan pekerjaan dengan baik dan bisa menghasilkan kinerja yang

${ }^{14}$ Wibowo, Manajemen Kinerja (Jakarta: Kharisma Putra Utama Offset, 2016), 86. 
baik dan pasien bisa merasa puas dengan pelayanan yang ada pada Rumah Sakit Ratumbuysang. ${ }^{15}$

2. Variabel kompetensi memiliki pengaruh yang lebih besar terhadap variabel kinerja karyawan dibanding dengan variabel komitmen dan pengembangan karir. Penelitian ini menunjukkan bahwa rendahnya kompetensi karyawan Bank Rakyat Indonesia Wilayah Pekanbaru maka menurunnkan kinerja karywan itu sendiri. ${ }^{16}$

3. Penelitian yang mengukur variabel kompetensi terhadap kinerja pimpinan menunjukkan variabel kompetensi manajemen diri yang lebih dominan memengaruhi kinerja pimpinan. Kompetensi manajemen diri berkaitan dengan kemampuan mengelola kondisi fisik dan psikologis dalam bekerja. Ketidaknyamanan dapat memengaruhi kinerja individual dan organisasi. ${ }^{17}$

4. Penelitian korelasi menunjukkan bahwa kompetensi SDM menunjukkan pengaruh signifikan terhadap kinerja. Pengaruh variabel pengetahuan ternyata tidak signifikan terhadap kinerja karena nilainya negatif dan sangat kecil, tetapi dua variabel yaitu ketrampilan dan kemampuan memiliki pengaruh yang signifikan sehingga kedua variabel ini perlu diperhatikan dalam mengembangkan meningkatkan kinerja UKM. ${ }^{18}$

5. Kompetensi memiliki pengaruh yang positif dan signifikan terhadap kinerja karyawan. Artinya kompetensi karyawan menstimulir optimasi pembentukan kinerja karyawan dalam bekerja di PT. Frisian Flag Indonesia wilayah Jawa Barat. Kompetensi itu meliputi kompetensi intelekstual, emosional, dan sosial. ${ }^{19}$

${ }^{15}$ Christilia O. Posuma, "Kompetensi, Kompensasi, Dan Kepemimpinan Pengaruhnya Terhadap Kinerja Karyawan Pada Rumah Sakit Ratumbuysang Manado," Jurnal EMBA: Jurnal Riset Ekonomi, Manajemen, Bisnis Dan Akuntansi 1, no. 4 (October 20, 2013): 646-56.

${ }^{16}$ Angga Rahyu Shaputra and Susi Hendriani, "Pengaruh Kompetensi, Komitmen Dan Pengembangan Karir Terhadap Kinerja Karyawan PT. Bank Rakyat Indonesia (Persero) Kantor Wilayah Pekanbaru," Jurnal Tepak Manajemen Bisnis 7, no. 1 (May 25, 2015): 1-17.

${ }^{17}$ Togap Simangunsong, Sri Indarti, and Zulfadil Zulfadil, "Pengaruh Kompetensi Terhadap Kinerja Pimpinan (Studi Kasus Pada PT. Drilinco Di PT.

Chevron Pacific Indonesia Sumatera)," Jurnal Ekonomi 22, no. 4 (August 1, 2018): 124.

${ }^{18}$ I. D. K. R. Ardiana, I. A. Brahmayanti, and Subaedi Subaedi, "Kompetensi SDM UKM Dan Pengaruhnya Terhadap Kinerja UKM Di Surabaya," Jurnal Manajemen Dan Kewirausahaan 12, no. 1 (2010): 54.

${ }^{19}$ Marliana Budhiningtias Winanti, "Pengaruh Kompetensi Terhadap Kinerja Karyawan (Survei Pada PT. Frisian Flag Indonesia Wilayah Jawa Barat)," Majalah Ilmiah UNIKOM 7, no. 2 (May 12, 2011): 265-66. 


\section{Metode}

Data kuantitatif dari indikator kompetensi diri (X) dan kinerja pekerja (Y) diolah menggunakan analisis variansi yang disebut dengan ANAVA. Analisis ini digunakan untuk menguji perbedaan rata-rata untuk kelompok sampel yang berjumlah lebih dari dua. ${ }^{20}$ Selanjutnya dilakukan analisis Classification and Regression Trees (CART). "CART analysis is a tree-building technique which is unlike traditional data analysis methods." ${ }^{21}$ Analisis sederhana yang dapat memperjelas variabel "penting" pada data yang tersedia untuk menjelaskan variabel tersebut. ${ }^{22}$

\section{Hasil dan Pembahasan}

\section{Profil Responden}

Responden Berdasarkan Jenis Kelamin dalam penelitian ini terdiri dari 32 responden terdiri dari 3 orang atau 9,4\% Pekerja yang berjenis kelamin perempuan, sedangkan yang berjenis kelamin laki-laki sebanyak 29 orang atau sebesar 90,6\%. Disimpulkan bahwa jumlah Pekerja GKII Daerah Kota Samarinda Wilayah Kalimantan Timur yang berjenis kelamin Laki-Laki lebih banyak dari pada responden yang berjenis kelamin perempuan.

Responden Berdasarkan Usia, diketahui bahwa dari 32 responden terdiri dari 3 orang atau 9,4\% Pekerja yang berusia kurang dari atau sama dengan 30 tahun, sebanyak 6 orang atau sebesar 18,8\% Pekerja yang berusia $31-40$ tahun, sebanyak 12 orang atau sebesar 37,5\% Pekerja yang berusia 41 - 50 tahun, sebanyak 7 orang atau 21,9\% Pekerja yang berusia 51 - 60 tahun, dan sebanyak 4 orang atau 12,5\% Pekerja yang berusia sama dengan atau lebih dari 61 tahun. Disimpulkan bahwa jumlah Pekerja GKII Daerah Kota Samarinda Wilayah Kalimantan Timur yang berusia 41-50 tahun lebih banyak dari pada Pekerja yang berusia kurang dari atau sama dengan 30 tahun, 31-40 tahun, 51-60 tahun dan sama dengan atau lebih dari 61 tahun.

Responden Berdasarkan Pendidikan, diketahui bahwa dari 32 responden terdiri dari 4 orang atau 12,5\% Pekerja yang berpendidikan Diploma III, sebanyak 4 orang atau sebesar 12,5\% Pekerja yang

${ }^{20}$ Mikha Agus Widiyanto, Statistika Untuk Penelitian Bidang Teologi, Pendidikan Agama Kristen, \& Pelayanan Gereja: Lemgkap Dengan Konsep Dan Aplikasi SPSS (Bandung: Kalam Hidup, 2014), 183.

${ }^{21}$ Roger J. Lewis, "An Introduction to Classification and Regression Tree (CART) Analysis" (2000),

https://pdfs.semanticscholar.org/6d4a/347b99d056b7blf28218728flb73e64cbbac.pdf.

22 Jake Morgan, "Classification and Regression Tree Analysis" (Boston: Boston University, 2014), https:/www.bu.edu/sph/files/2014/05/MorganCART.pdf. 
berpendidikan Sarjana (S1), sebanyak 23 orang atau sebesar 71,9\% Pekerja yang berpendidikan Magister (S2), dan sebanyak 1 orang atau 3,1\% Pekerja yang berpendidikan Doktoral (S3). Disimpulkan bahwa jumlah Pekerja GKII Daerah Kota Samarinda Wilayah Kalimantan Timur yang berpendidikan Magister (S2) lebih banyak dari pada Pekerja yang berpendidikan Diploma III, Sarjana (S1) dan Doktoral (S3).

\section{Deskripsi Data Variabel Penelitian}

\section{Kompetensi Diri (X)}

Berdasarkan data skor total untuk keseluruhan instrumen yang telah dikumpulkan dari variabel Kompetensi Diri, didapatkan hasil perhitungan sebagai berikut: Rentang skor empiris didapatkan 170 sampai dengan 219. Nilai rata-rata didapatkan sebesar 193,22; simpangan baku sebesar 13,912 dan varians sebesar 193,531. Kompetensi Diri Pekerja GKII Daerah Kota Samarinda berada pada kategori cukup baik. Berdasarkan skor rata-rata untuk setiap Dimensi dari Kompetensi Diri diperoleh hasil analisis sebagai berikut.

Tabel 1. Analisis Deskripsi Dimensi Kompetensi Diri

\begin{tabular}{lr|r|r|r|r|r}
\hline \multicolumn{7}{c}{ Descriptive Statistics } \\
\hline & $\mathrm{N}$ & $\begin{array}{c}\text { Mini- } \\
\text { mum }\end{array}$ & $\begin{array}{c}\text { Maxi- } \\
\text { mum }\end{array}$ & Mean & $\begin{array}{c}\text { Std. } \\
\text { Deviation }\end{array}$ & Variance \\
\hline Kompetensi Spiritual & 32 & 3 & 5 & 4.33 & .469 & .220 \\
\hline Kompetensi Profesional & 32 & 4 & 5 & 4.33 & .320 & .103 \\
\hline Kompetensi Kepribadian & 32 & 4 & 5 & 4.31 & .352 & .124 \\
\hline Kompetensi Sosial & 32 & 3 & 5 & 4.14 & .421 & .177 \\
\hline Valid N (listwise) & 32 & & & & & \\
\hline
\end{tabular}

Berdasarkan nilai rata-rata dapat disimpulkan bahwa kompetensi Spiritual dan Kompetensi Profesional Pekerja GKII Daerah Kota Samarinda Wilayah Kalimantan Timur yang lebih baik dibandingkan Kompetensi Kepribadian dan Sosial.

\section{Kinerja Pekerja (Y)}

Berdasarkan data yang telah dikumpulkan dari variabel Kinerja Pekerja didapatkan hasil perhitungan sebagai berikut. Rentang skor empiris didapatkan 86 sampai dengan 117. Nilai rata-rata didapatkan sebesar 100,91; simpangan baku diperoleh sebesar 8,224 dan varians sebesar 67,636. Kinerja Pekerja GKII Daerah Kota Samarinda berada pada kategori baik. 
Tabel 2. Analisis Deskripsi Dimensi Kinerja Pekerja

\begin{tabular}{cc|r|r|r|r|r}
\hline \multicolumn{7}{c}{ Descriptive Statistics } \\
\hline & $\mathrm{N}$ & $\begin{array}{c}\text { Mini- } \\
\text { mum }\end{array}$ & $\begin{array}{c}\text { Maxi- } \\
\text { mum }\end{array}$ & Mean & $\begin{array}{c}\text { Std. } \\
\text { Deviation }\end{array}$ & Variance \\
\hline Kepatuhan & 32 & 3.67 & 5.00 & 4.5466 & .39530 & .156 \\
\hline Prestasi Kerja & 32 & 3.56 & 4.89 & 4.2616 & .41054 & .169 \\
\hline $\begin{array}{c}\text { Leadership \& } \\
\text { Management } \\
\text { Effectivness }\end{array}$ & 32 & 3.22 & 4.89 & 3.9200 & .44449 & .198 \\
\hline $\begin{array}{c}\text { Valid N } \\
\text { (listwise) }\end{array}$ & 32 & & & & & \\
\hline
\end{tabular}

Berdasarkan nilai rata-rata dapat disimpulkan bahwa Dimensi Kepatuhan merupakan Kinerja Pekerja GKII Daerah Kota Samarinda Wilayah Kalimantan Timur yang lebih baik dibandingkan dengan dimensi lainnya.

\section{Pengujian Hipotesis Pengaruh Kompetensi Diri terhadap Kinerja Pekerja}

Berdasarkan hasil analisis diperoleh persamaan garis regresi $\hat{Y}=$ $22,270+0,407 X_{1}$. Sebelum digunakan untuk predikasi terlebih dahulu dilakukan pengujian signifikansi koefisien regresi. Hasil pengujian koefisien regresi diperoleh nilai $\mathrm{F}$ hitung sebesar 27,027 dengan P-value sebesar 0,000 yang lebih kecil dari 0,05 yang berati signifikan. Berikut ini ringkasan hasil analisis untuk uji linearitas regresi dan uji keberartian regresi sebagai berikut:

Tabel 3. ANAVA Pengujian Signifikansi Persamaan Regresi Kinerja (Y) atas Kompetensi Diri $\left(\mathrm{X}_{1}\right) \hat{\mathrm{Y}}=22,270+0,407 \mathrm{X}_{1}$

\begin{tabular}{|c|c|c|c|c|c|c|}
\hline \multicolumn{7}{|c|}{ ANOVA $^{\mathrm{a}}$} \\
\hline Mod & & $\begin{array}{c}\text { Sum of } \\
\text { Squares }\end{array}$ & Df & $\begin{array}{l}\text { Mean } \\
\text { Square }\end{array}$ & $\mathrm{F}$ & Sig. \\
\hline \multirow[t]{3}{*}{$\bar{l}$} & $\begin{array}{l}\text { Regressio } \\
\mathrm{n}\end{array}$ & 993.702 & 1 & 993.702 & 27.027 & $.000^{\mathrm{b}}$ \\
\hline & Residual & 1103.017 & 30 & 36.767 & & \\
\hline & Total & 2096.719 & 31 & & & \\
\hline
\end{tabular}

a. Dependent Variable: Kinerja

b. Predictors: (Constant), Kompetensi 
Tabel 4. Koefisien Pengujian Signifikansi Persamaan Regresi Kinerja (Y) atas Kompetensi Diri $\left(\mathrm{X}_{1}\right)$

\begin{tabular}{|c|c|c|c|c|c|c|}
\hline \multicolumn{7}{|c|}{ Coefficients $^{\mathrm{a}}$} \\
\hline \multirow{2}{*}{\multicolumn{2}{|c|}{ Model }} & \multicolumn{2}{|c|}{$\begin{array}{c}\text { Unstandardized } \\
\text { Coefficients }\end{array}$} & \multirow{2}{*}{$\begin{array}{c}\begin{array}{c}\text { Standardi-zed } \\
\text { Coefficients }\end{array} \\
\text { Beta } \\
\end{array}$} & \multirow[b]{2}{*}{$\mathrm{T}$} & \multirow[b]{2}{*}{ Sig. } \\
\hline & & $\mathrm{B}$ & Std. Error & & & \\
\hline l & (Constant) & 22.270 & 15.164 & & 1.469 & .152 \\
\hline & Kompetensi & .407 & .078 & .688 & 5.199 & .000 \\
\hline
\end{tabular}

a. Dependent Variable: Kinerja

Penulis menyimpulkan bahwa terdapat pengaruh yang positif dan sangat signifikan antara Kompetensi Diri dengan Kinerja Pekerja. Hal ini berarti semakin baik kompetensi diri para pekerja GKII Daerah Kota Samarinda maka akan meningkatkan kinerjanya menjadi semakin baik.

Besarnya koefisien determinansi $\left(\mathrm{r}^{2} \mathrm{yl}\right)$ sebesar 0,456 mempunyai makna bahwa Kompetensi Diri memberikan kontribusi sebesar 45,6\% terhadap Kinerja Pekerja. Sedangkan sisanya sebesar 54,4\% dipengaruhi variabel lainnya yang tidak diteliti.

Berdasarkan hasil analisis korelasi antar Dimensi Kompetensi Diri dengan Kinerja Pekerja diperoleh hasil sebagai berikut:

Tabel 5. Analisis Korelasi Dimensi Kompetensi Diri dengan Kinerja

\begin{tabular}{|c|c|c|c|c|c|c|}
\hline \multicolumn{7}{|c|}{ Correlations } \\
\hline & & $\begin{array}{c}\text { Kiner- } \\
\text { ja }\end{array}$ & $\begin{array}{c}\text { Kom- } \\
\text { petensi } \\
\text { Spiri- } \\
\text { tual } \\
\end{array}$ & $\begin{array}{c}\text { Kompe- } \\
\text { tensi } \\
\text { Profe- } \\
\text { sional } \\
\end{array}$ & $\begin{array}{l}\text { Kompetensi } \\
\text { Kepribadian }\end{array}$ & $\begin{array}{c}\text { Kompetensi } \\
\text { Sosial }\end{array}$ \\
\hline \multirow[t]{3}{*}{ Kinerja } & $\begin{array}{l}\text { Pearson } \\
\text { Correlation }\end{array}$ & 1 & .280 & $.624^{* *}$ & $.713^{* *}$ & $.474^{* *}$ \\
\hline & $\begin{array}{l}\text { Sig. (2- } \\
\text { tailed) }\end{array}$ & & .120 & .000 & .000 & .006 \\
\hline & $\mathrm{N}$ & 32 & 32 & 32 & 32 & 32 \\
\hline \multirow{3}{*}{$\begin{array}{l}\text { Kompe- } \\
\text { tensi } \\
\text { Spiri- } \\
\text { tual }\end{array}$} & $\begin{array}{l}\text { Pearson } \\
\text { Correlation }\end{array}$ & .280 & 1 & $.564^{* *}$ & $399^{*}$ & $.410^{*}$ \\
\hline & $\begin{array}{l}\text { Sig. (2- } \\
\text { tailed) }\end{array}$ & .120 & & .001 & .024 & .020 \\
\hline & $\mathrm{N}$ & 32 & 32 & 32 & 32 & 32 \\
\hline \multirow{3}{*}{$\begin{array}{l}\text { Kompe- } \\
\text { tensi } \\
\text { Profe- } \\
\text { sional }\end{array}$} & $\begin{array}{l}\text { Pearson } \\
\text { Correlation }\end{array}$ & $.624^{* *}$ & $.564^{* *}$ & 1 & $.762^{* *}$ & $.577^{* *}$ \\
\hline & $\begin{array}{l}\text { Sig. (2- } \\
\text { tailed) }\end{array}$ & .000 & .001 & & .000 & .001 \\
\hline & $\mathrm{N}$ & 32 & 32 & 32 & 32 & 32 \\
\hline
\end{tabular}




\begin{tabular}{|c|c|c|c|c|c|c|}
\hline \multirow{3}{*}{$\begin{array}{l}\text { Kompe- } \\
\text { tensi } \\
\text { Kepri- } \\
\text { badian }\end{array}$} & $\begin{array}{l}\text { Pearson } \\
\text { Correlation }\end{array}$ & $.713^{* *}$ & $.399^{*}$ & $.762^{* *}$ & 1 & $.688^{* *}$ \\
\hline & $\begin{array}{l}\text { Sig. (2- } \\
\text { tailed) }\end{array}$ & .000 & .024 & .000 & & .000 \\
\hline & $\mathrm{N}$ & 32 & 32 & 32 & 32 & 32 \\
\hline \multirow{3}{*}{$\begin{array}{l}\text { Kompe- } \\
\text { tensi } \\
\text { Sosial }\end{array}$} & $\begin{array}{l}\text { Pearson } \\
\text { Correlation }\end{array}$ & $.474^{* *}$ & $.410^{*}$ & $.577^{* *}$ & $.688^{* *}$ & 1 \\
\hline & $\begin{array}{l}\text { Sig. (2- } \\
\text { tailed) }\end{array}$ & .006 & .020 & .001 & .000 & \\
\hline & $\mathrm{N}$ & 32 & 32 & 32 & 32 & 32 \\
\hline
\end{tabular}

**. Correlation is significant at the 0.01 level (2-tailed).

*. Correlation is significant at the 0.05 level (2-tailed).

Berdasarkan koefisien korelasi tersebut dapat disimpulkan bahwa Dimensi Kompetensi Kepribadian yang paling berpengaruh secara dominan terhadap peningkatan kinerja Pekerja.

Berdasarkan analisis Classification and Regression Trees diperoleh hasil sebagai berikut:

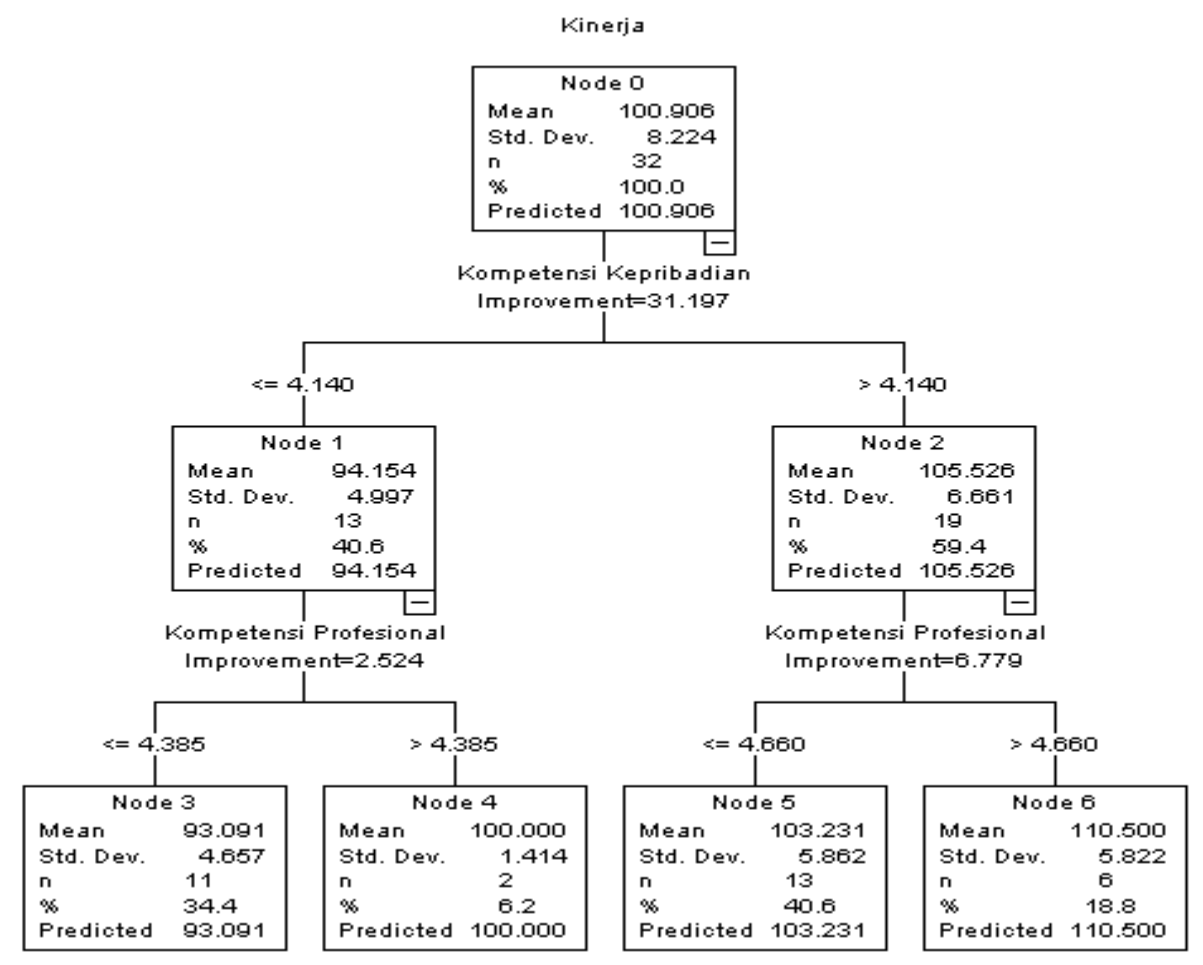

Gambar 2. Diagram Pohon Pengujian Dimensi Kompetensi Diri yang Dominan Memengaruhi Peningkatan Kinerja 
Dari hasil analisis di atas, menunjukkan bahwa Dimensi Kompetensi Kepribadian yang berpengaruh secara langsung dalam meningaktkan Kinerja Pekerja GKII Daerah Kota Samarinda sebesar 31,197. Meningkatkan Kompetensi Kepribadian akan berdampak terhadap peningkatan Kinerja Pekerja yang signifikan. Sedangkan Dimensi Kompetensi Profesional berpengaruh secara tidak langsung terhadap Kinerja Pekerja sebesar 9,303.

\section{Kesimpulan}

Beberapa penelitian hubungan kompetensi diri terhadap kinerja pekerja (karyawan/pegawai) menunjukkan hasil positif. Teori yang menyetakan semakin baik kompetensi diri pekerja maka semakin baik pula kinerja pekerja tersebut, Demikian pula sebaliknya, bila kompetensi pekerja rendah maka kinerja pekerja tersebut akan menurun. Oleh karena itu, kompetensi seorang pekerja perlu dioptimalkan untuk meningkatkan kinerja baik dalam perusahaan, organisasi, dan dalam pelayanan gereja.

Pengaruh yang positif dan sangat signifikan antara Kompetensi Diri dengan Kinerja Pekerja. Hal ini berarti semakin baik kompetensi diri para pekerja GKII Daerah Kota Samarinda maka semakin baik pula Kinerjanya. Berdasarkan hasil analisis korelasi antara Dimensi Kompetensi Diri dengan kinerja dan analisis Classifacion and Regression Trees bahwa Dimensi Kompetensi kepribadian yang paling berpengaruh secara dominan terhadap peningkatan kinerja Pekerja. Dengan meningkatkan kompetensi kepribadian menjadi lebih baik dan mampu memberikan keteladanan seperti Kristus dalam pelaksanaan tugas pelayanan maka kinerja Pekerja akan semakin meningkat dan menjadi semakin baik.

\section{Kepustakaan}

Ardiana, I. D. K. R., I. A. Brahmayanti, and Subaedi Subaedi. "Kompetensi SDM UKM Dan Pengaruhnya Terhadap Kinerja UKM Di Surabaya." Jurnal Manajemen Dan Kewirausahaan 12, no. 1 (2010): 4255.

Battistelli, Adalgisa, Maura Galletta, Christian Vandenberghe, and Carlo Odoardi. "Perceived Organisational Support, Organisational Commitment and Self-Competence among Nurses: A Study in Two Italian Hospitals." Journal of Nursing Management 24, no. 1 (January 2016): 1-9. https://doi.org/10.11l1/jonm.12287. 
Berdicchia, Domenico, Francesco Nicolli, and Giovanni Masino. "Job Enlargement, Job Crafting and the Moderating Role of SelfCompetence." Journal of Managerial Psychology 31, no. 2 (March 14, 2016). https://doi.org/10.1108/JMP-01-2014-0019.

Budhiningtias Winanti, Marliana. "Pengaruh Kompetensi Terhadap Kinerja Karyawan (Survei Pada PT. Frisian Flag Indonesia Wilayah Jawa Barat)." Majalah Ilmiah UNIKOM 7, no. 2 (May 12, 2011): 24967.

Data Statistik Gereja Kemah Injil Indonesia Daerah Kota Samarinda tahun 2016.

Ellis, D. W. Metode Penginjilan. Jakarta: Yayasan Komunikasi Bina Kasih/OMF, 1993.

Fudyartanta, Ki. Psikologi Kepribadian. Yogyakarta: Pustaka Pelajar, 2012.

Ghazali, M., Nurseha Ghazali. Deteksi Kepribadian. Jakarta: Bumi Aksara, 2016.

Lewis, Roger J. "An Introduction to Classification and Regression Tree (CART) Analysis." presented at the the 2000 Annual Meeting of the Society for Academic Emergency Medicine, n San Francisco, California., 2000.

https://pdfs.semanticscholar.org/6d4a/347b99d056b7blf28218728fl b73e64cbbac.pdf.

Luthans, Fred. Perilaku Organisasi. Yogyakarta: ANDI Offset, 2006.

Maxwell, John C. Mengembangkan Kepemimpinan di dalam Diri Anda. Jakarta: Binarupa Aksara, 1995.

Morgan, Jake. "Classification and Regression Tree Analysis." Boston: Boston University, 2014. https://www.bu.edu/sph/files/2014/05/MorganCART.pdf.

Posuma, Christilia O. "Kompetensi, Kompensasi, Dan Kepemimpinan Pengaruhnya Terhadap Kinerja Karyawan Pada Rumah Sakit Ratumbuysang Manado." Jurnal EMBA: Jurnal Riset Ekonomi, Manajemen, Bisnis Dan Akuntansi 1, no. 4 (October 20, 2013): 646-56.

Robbins, Stephen P. dan Timoty A Judge. Perilaku Organisasi. Jakarta: Salemba Empat, 2015.

Sanjaya, Wina. Strategi Pembelajaran Berorientasi Standar Proses Pendidikan. Jakarta: Kencana Prenada Media Group, 2006.

Shaputra, Angga Rahyu, and Susi Hendriani. "Pengaruh Kompetensi, Komitmen Dan Pengembangan Karir Terhadap Kinerja Karyawan PT. Bank Rakyat Indonesia (Persero) Kantor Wilayah Pekanbaru." Jurnal Tepak Manajemen Bisnis 7, no. 1 (May 25, 2015): 1-17.

Simangunsong, Togap, Sri Indarti, and Zulfadil Zulfadil. "Pengaruh Kompetensi Terhadap Kinerja Pimpinan (Studi Kasus Pada PT. 
Drilinco Di PT. Chevron Pacific Indonesia Sumatera)." Jurnal Ekonomi 22, no. 4 (August 1, 2018): 110-26.

Wibowo. Budaya Organisasi, Sebuah Kebutuhan Untuk Meningkatkan Kinerja Jangka Panjang. Jakarta: RajaGrafindo Persada, 2016.

Wibowo. Manajemen Kinerja. Jakarta: Kharisma Putra Utama Offset, 2016. Widiyanto, Mikha Agus. Statistika Untuk Penelitian Bidang Teologi, Pendidikan Agama Kristen, \& Pelayanan Gereja: Lemgkap Dengan Konsep Dan Aplikasi SPSS. Bandung: Kalam Hidup, 2014. 